\title{
Scents from Brazilian Cerrado: chemical composition of the essential oil from Psidium laruotteanum Cambess (Myrtaceae)
}

Fernando C. M. Medeiros, Cláudio H. S. Del Menezzi, Roberto F. Vieira, Yasmin F. M. Fernandes, Marcelly C. S. Santos \& Humberto R. Bizzo

To cite this article: Fernando C. M. Medeiros, Cláudio H. S. Del Menezzi, Roberto F. Vieira, Yasmin F. M. Fernandes, Marcelly C. S. Santos \& Humberto R. Bizzo (2018) Scents from Brazilian Cerrado: chemical composition of the essential oil from Psidium laruotteanum Cambess (Myrtaceae), Journal of Essential Oil Research, 30:4, 253-257, DOI: 10.1080/10412905.2018.1462740

To link to this article: https://doi.org/10.1080/10412905.2018.1462740

\section{冊 Published online: 23 Apr 2018.}

\section{Submit your article to this journal ๘}

III Article views: 69

Q View related articles ¿

View Crossmark data $\nearrow$ 


\title{
Scents from Brazilian Cerrado: chemical composition of the essential oil from Psidium laruotteanum Cambess (Myrtaceae)\#
}

\author{
Fernando C. M. Medeiros ${ }^{a}$, Cláudio H. S. Del Menezzi ${ }^{a}$, Roberto F. Vieira ${ }^{b}$, Yasmin F. M. Fernandesc, \\ Marcelly C. S. Santos ${ }^{\complement}$ and Humberto R. Bizzoc (D)

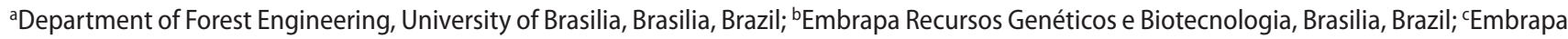 \\ Agroindústria de Alimentos, Rio de Janeiro, Brazil
}

ABSTRACT

The chemical composition of the essential oils from the leaves from three different populations of Psidium laruotteanum Cambess. (Myrtaceae) from the Brazilian Cerrado were analysed by GC-FID and GC-MS. Forty-five components were identified in the oils. The oil yields were $0.3 \%$ (dry weight basis). The oil was rich in monoterpenes and major compounds identified were $p$-cymene (19.4$34.8 \%), 1,8$-cineole (6.9-19.2\%) and a-pinene (9.2-11.4\%). Although collected in different locations and years, the essential oils composition were quite similar, both qualitative and quantitatively.

\section{ARTICLE HISTORY}

Received 29 October 2017 Accepted 2 April 2018

\section{KEYWORDS}

Psidium laruotteanum;

Myrtaceae; Cerrado;

p-cymene; essential oil composition

\section{Introduction}

Brazilian biodiversity comprises $c a$. one-sixth of the total plant species, and includes different biomes, as the Amazon rainforest, the Atlantic Forest and a savannah area in Central Brazil, called Cerrado (1). Amazon forest is the largest and, by far, the most known Brazilian biome. However, Cerrado, the second largest one, is the most threaten by anthropic pressure. Only a small fraction of the 12,000 known botanical species was chemically investigated, making Cerrado a very promising source for flavour and fragrance applications (2).

Among many species of Myrtaceae, the genus Psidium stands out as one of the most common in the Cerrado. In Brazil fifty-nine species are found, forty-four of them endemic, and thirty-one native from the Cerrado area (3).

Psidium laruotteanum Cambess is a $2 \mathrm{~m}$ high, wild, small tree, largely distributed in small populations in Central Brazil at Cerrado vegetation (3). It is locally known as 'araçá-cascudo'. The fruit of this little shrub is about the size of an ordinary gooseberry, and the flavour is richer than that of any of the other 'araçás' (4). It serves as food for many species of animals and man. The fruit is of excellent taste, much appreciated for fresh consumption and in the form of jams and jellies, but productivity is low.
Previous studies with $P$. laruotteanum described the content of total phenolic compounds of an infusion from the leaves to be $576.56 \mathrm{mg}$ of gallic acid equivalents per gram of dry extract (5). The authors associated this high phenolic content with a very strong antioxidant activity, evaluated by the DPPH method.

The anti-parasitic activity of extracts (hexane, ethyl acetate and ethanol) from $P$. laruotteanum was evaluated for Plasmodium falciparum, Trypanosoma cruzi and T. brucei gambiense (6). The ethyl acetate extract from the stems was found to be active against $P$. falciparum $\left(\mathrm{IC}_{50}\right.$ : $16.3 \mu \mathrm{g} / \mathrm{mL}$ ), while the hexane and ethyl acetate extracts from the leaves showed activity against $T$. brucei gambiense ( $\mathrm{IC}_{50}: 3.9 \mu \mathrm{g} / \mathrm{mL}$, and $6.8 \mu \mathrm{g} / \mathrm{mL}$, respectively). Reference compounds used were chloroquine $\left(\mathrm{IC}_{50}: 24 \mathrm{nM}\right)$, pentamidine $\left(\mathrm{IC}_{50}: 4.0 \mathrm{nM}\right)$ and nifurtimox $\left(\mathrm{IC}_{50}: 0.6 \mu \mathrm{g} / \mathrm{mL}\right)$, respectively. The authors reported no cytotoxic activity against L6 cells for the tested extracts.

The essential oil of P. laruotteanum was tested against xylophagus fungi, Gloeophyllum trabeum and Trametes versicolor. A very small inhibition (ca. 9\%) was observed when pure oil was tested, but only against G. trabeum (7).

Herein, we report the results of the analysis of the essential oil from the leaves of three different populations of P. laruotteanum collected in the Cerrado biome. To the

CONTACT Humberto R.Bizzo humberto.bizzo@embrapa.br

\#Presented in part as a poster at the 46th International Symposium on Essential Oils. Part 7 in the series Scents from Brazilian Cerrado.

(C) 2018 Informa UK Limited, trading as Taylor \& Francis Group 
Table 1. Plant collection data.

\begin{tabular}{lll}
\hline Sample code & Place & Collection date \\
\hline 2410 & Altitude: $1137 \mathrm{~m}$ & 10 April 2012 \\
& Latitude: $15^{\circ} 36^{\prime} 29^{\prime \prime} \mathrm{S}$ & \\
& Longitude: $47^{\circ} 44^{\prime} 28^{\prime \prime} \mathrm{W}$ & \\
2436 & Altitude: $1062 \mathrm{~m}$ & 5 June 2012 \\
& Latitude: $15^{\circ} 54^{\prime} 00^{\prime \prime} \mathrm{S}$ & \\
& Longitude: $47^{\circ} 56^{\prime} 20^{\prime \prime} \mathrm{W}$ & \\
2605 & Altitude: $1113 \mathrm{~m}$ & 11 June 2013 \\
& Latitude: $15^{\circ} 57^{\prime} 03^{\prime \prime} \mathrm{S}$ & \\
& Longitude: $47^{\circ} 54^{\prime} 46^{\prime \prime} \mathrm{W}$ & \\
\hline
\end{tabular}

best of our knowledge, this is the first report on the essential oil composition of this species.

\section{Experimental part}

\subsection{Plant material}

Leaves from plants of three different populations (minimum five individuals per population), labelled as 2410 , 2436 and 2605, were collected and dried to constant weight in an oven at $38^{\circ} \mathrm{C}$ with forced ventilation. All sampling areas were situated in Brasilia, Brazil. Voucher specimens were deposited in the herbarium of Embrapa Genetic Resources and Biotechnology (82,843 and $84,485)$. Sampling code, place of collection and time of the year are presented in Table 1. According to Brazilian law, collection and access were authorized by the Ministry of Environment (process IBAMA 02001.003166/2013-26).

\subsection{Distillation of the essential oil}

Dried leaves from a representative sample of each population collected were subjected to hydrodistillation in a modified Clevenger-type apparatus for $2 \mathrm{~h}$. After distillation, the oil was collected, dried with anhydrous sodium sulfate $\left(\mathrm{Na}_{2} \mathrm{SO}_{4}\right)$ and stored in a freezer at $-8^{\circ} \mathrm{C}$ for later analysis.

\subsection{Analysis of the essential oil}

The essential oil was diluted in dichloromethane in the proportion of $1 \%$, and then $1.0 \mu \mathrm{L}$ of the solution was injected (split 1:20) into an Agilent $6890 \mathrm{~N}$ gas chromatograph equipped with a flame ionization detector (GC-FID) and a HP-5MS fused silica capillary column (Agilent Technologies, $5 \%$ phenyl-methylpolysiloxane, $30 \mathrm{~m} \times 0.25 \mathrm{~mm} \times 0.25 \mu \mathrm{m})$. Hydrogen was used as carrier gas at a flow rate of $1.0 \mathrm{~mL} /$ min. The oven temperature was programmed from 60 to $240^{\circ} \mathrm{C}$ at $3{ }^{\circ} \mathrm{C} / \mathrm{min}$. Injector temperature was kept at $250{ }^{\circ} \mathrm{C}$ and detector temperature at $280^{\circ} \mathrm{C}$. The quantitative data (percentage composition) was obtained by normalization. Samples were injected in triplicate.
Analyses by GC-MS were performed on an Agilent $5973 \mathrm{~N}$ mass selective detector coupled to an Agilent 6890 gas chromatograph fitted with a HP-5MS fused silica capillary column (Agilent Technologies, 5\% phenyl-methylpolysiloxane, $30 \mathrm{~m} \times 0.25 \mathrm{~mm} \times 0.25 \mu \mathrm{m})$. Helium was used as carrier gas at $1.0 \mathrm{~mL} / \mathrm{min}$. The mass detector was operated in electronic ionization mode $(70 \mathrm{eV})$, at $3.15 \mathrm{scans} / \mathrm{s}$, with mass range from 40 to $450 \mathrm{u}$. Transfer line was kept at $260^{\circ} \mathrm{C}$, ion source at $230^{\circ} \mathrm{C}$ and analyzer at $150{ }^{\circ} \mathrm{C}$. Oven temperature programme and injection procedure were the same as above.

The components were identified by comparison of their mass spectra with those from the Wiley Registry of Mass Spectral Data (8), as well as by their linear retention indices (LRI), calculated according to Van Den Dool and Kratz (9), after the injection of a homologous series of $n$-alkanes $\left(\mathrm{C}_{7}-\mathrm{C}_{26}\right)$ in the same conditions as above, and compared to literature data (10).

\section{Results and discussion}

The essential oil yields (dry weight base) were $0.3 \%$ (2410), $0.4 \%$ (2436) and $0.3 \%$ (2605). Forty-five compounds were identified in the oils, representing $98.8 \%$ (2410 and 2436) and $97.1 \%$ (2605) of the total.

A rather similar composition was found for the three oils. They were rich in monoterpenes and oxygenated monoterpenoids, accounting for $90 \%$ or more of the oils composition. For all samples, $p$-cymene appeared as the major compound $(24.8,19.4$ and $34.0 \%$, respectively, for samples 2410, 2436 and 2605). Consequently, very few sesquiterpenes and their oxygenated derivatives were found. The oils compositions are shown in Table 2, and a representative chromatogram with the oil profile is presented in Figure 1.

Although plants were collected from the wild, and not subjected to control conditions, the edaphoclimatic conditions of the three populations were nearly the same. They were collected in different months (April and June) and years (2012 and 2013), but in the same season, autumn in south hemisphere, which is a dry period in the Cerrado area. Climate conditions, such as temperatures, length of the day and rain occurrence were the same for the areas of sampling, which were not far (approximately $50 \mathrm{~km}$ ) from each other, as well as the soil type, red latosol. The populations collected were in the same vegetative stage, without flowers nor fruits.

The oils are rich in compounds with a terpinene-like structure, such as alpha and gamma terpinene, terpinolene, $p$-cymene, and the respective oxygenated compounds (terpineols, cymenols, and thymol), all closely related considering their biosynthetic pathway. 
Table 2. Chemical composition of the essential oils of $P$. laruotteanum.

\begin{tabular}{|c|c|c|c|c|c|c|}
\hline Peak & LRI $^{\mathrm{a}}$ calc & $\mathrm{LRI}^{\mathrm{b}}$ lit & Identification & 2410 & 2436 & 2605 \\
\hline 1 & 925 & 924 & a-thujene & 0.1 & 0.1 & $t$ \\
\hline 2 & 932 & 932 & a-pinene & 13.4 & 11.6 & 9.2 \\
\hline 3 & 947 & 953 & Camphene & 0.1 & 0.4 & 0.6 \\
\hline 4 & 976 & 975 & Sabinene & 1.0 & 0.2 & n.d. \\
\hline 5 & 990 & 991 & Myrcene & 1.0 & 0.6 & 0.6 \\
\hline 6 & 1005 & 1005 & a-phellandrene & 1.9 & 1.6 & 0.2 \\
\hline 7 & 1010 & 1011 & $\delta$-3-carene & 1.2 & 1.1 & 1.4 \\
\hline 8 & 1016 & 1014 & a-terpinene & 2.2 & 1.1 & 0.2 \\
\hline 9 & 1023 & 1023 & p-cymene & 24.8 & 19.4 & 34.8 \\
\hline 10 & 1026 & 1024 & Limonene & 3.0 & 10.2 & 7.9 \\
\hline 11 & 1029 & 1026 & 1,8-cineole & 19.2 & 6.9 & 12.5 \\
\hline 12 & 1045 & 1044 & $(E)$ - $\beta$-ocimene & n.d. & 1.4 & n.d. \\
\hline 13 & 1056 & 1054 & $\mathrm{\gamma}$-terpinene & 3.6 & 14.0 & 6.9 \\
\hline 14 & 1070 & 1067 & cis linalool oxide & n.d. & 0.1 & 0.2 \\
\hline 15 & 1087 & 1086 & Terpinolene & 3.6 & 5.1 & 0.9 \\
\hline 16 & 1099 & 1097 & Linalool & 2.1 & 3.4 & 2.0 \\
\hline 17 & 1111 & 1114 & endo-fenchol & 0.3 & 0.2 & 0.5 \\
\hline 18 & 1124 & 1122 & a-campholenal & n.d. & 0.2 & 0.3 \\
\hline 19 & 1135 & 1139 & $(E)$-pinocarveol & 0.8 & 0.1 & 0.2 \\
\hline 20 & 1162 & 1162 & Borneol & 0.5 & 0.6 & 1.3 \\
\hline 21 & 1174 & 1177 & Terpinen-4-ol & 6.3 & 5.8 & 2.7 \\
\hline 22 & 1185 & 1183 & $p$-cymen-8-ol & $t$ & n.d. & 0.4 \\
\hline 23 & 1188 & 1189 & a-terpineol & 4.2 & 4.5 & 6.0 \\
\hline 24 & 1193 & 1194 & Myrtenol & n.d. & n.d. & 0.5 \\
\hline 25 & 1216 & 1218 & Fenchyl acetate & $t$ & 0.1 & 0.4 \\
\hline 26 & 1282 & 1283 & Isobornyl acetate & $t$ & 1.7 & 1.4 \\
\hline 27 & 1284 & 1289 & Thymol & $t$ & 0.1 & 0.6 \\
\hline 28 & 1290 & 1289 & $p$-cymen-7-ol & $t$ & 0.3 & 0.6 \\
\hline 29 & 1348 & 1346 & a-terpinyl acetate & n.d. & 1.7 & n.d. \\
\hline 30 & 1371 & 1374 & a-copaene & 0.3 & 0.3 & 0.2 \\
\hline 31 & 1413 & 1419 & $(E)$-caryophyllene & 0.6 & $t$ & n.d. \\
\hline 32 & 1447 & 1455 & a-humulene & 0.7 & 0.2 & n.d. \\
\hline 33 & 1508 & 1514 & ү-cadinene & 0.2 & 0.3 & $t$ \\
\hline 34 & 1518 & 1523 & $\delta$-cadinene & 0.6 & 0.6 & 0.2 \\
\hline 35 & 1575 & 1578 & Caryophyllene oxide & 0.8 & 0.8 & n.d. \\
\hline 36 & 1583 & 1590 & Globulol & 0.4 & 0.8 & 1.9 \\
\hline 37 & 1584 & 1592 & Viridiflorol & 0.5 & 0.2 & 0.3 \\
\hline 38 & 1586 & 1595 & Cubeban-11-ol & 0.1 & 0.1 & 0.7 \\
\hline 39 & 1594 & 1600 & Rosifoliol & $t$ & 0.3 & 0.6 \\
\hline 40 & 1601 & 1608 & Humulene epoxide II & 0.9 & n.d. & n.d. \\
\hline 41 & 1621 & 1629 & 1-epi-cubenol & 0.8 & 0.8 & 0.5 \\
\hline 42 & 1634 & 1640 & epi-a-cadinol & 0.5 & 1.5 & 0.6 \\
\hline 43 & 1642 & 1646 & a-muurolol & 0.7 & 0.4 & 0.6 \\
\hline 44 & 1645 & 1651 & $\beta$-eudesmol & 1.0 & $t$ & $t$ \\
\hline \multirow[t]{6}{*}{45} & 1647 & 1654 & a-eudesmol & 1.4 & $t$ & $t$ \\
\hline & & & Total: & 98.8 & 98.8 & 97.9 \\
\hline & & & Total monoterpene hydrocarbons: & 55.9 & 66.8 & 62.7 \\
\hline & & & Total oxygenated monoterpenes: & 33.4 & 25.7 & 29.6 \\
\hline & & & Total sequiterpenes hydrocarbons: & 2.4 & 1.4 & 0.4 \\
\hline & & & Total oxygenated sesquiterpenes: & 7.1 & 4.9 & 5.2 \\
\hline
\end{tabular}

an a HP-5MS column, according to Ref. (9).

${ }^{\text {b} A c c o r d i n g ~ t o ~ R e f . ~}(10) ; t$ : trace $(<0.1 \%) ;$ n.d.: not detected.

It is interesting to observe that for the sample 2436, in which a lower content of $p$-cymene was recorded, higher concentrations of specifically other terpinene-like isomers were found (limonene, $\gamma$-terpinene and terpinolene). This seems to be related either to a more restrict biosynthetic profile, which points out to a lower genomic variability among the three populations, or to the effect of non-enzymatic and abiotic conditions. Albeit the last possibility has been demonstrated to occur with other plant families (11), the former is more likely to have occurred with the samples of $P$. laruotteanum analysed, since edaphoclimatic conditions were quite similar within the collection sites. Another difference that may impart the observed variation on the oil composition is that sample 2436 was harvested in a more disturbed area, while 2410 and 2605 were collected from well-preserved areas, which can might explain some different content in some specific compounds.

The oil composition of $P$. laruotteanum was quite different from the oils of other Brazilian Psidium. P. myrsinites DC., for instance, collected in the same area and season, yielded an oil rich in caryophyllene oxide, $\beta$-caryophyllene and other sesquiterpenoids, but not in monoterpenes (12). P. myrsinoides O. Berg, also from the Cerrado and a closely related species to $P$. myrsinites, yielded an oil rich in $\beta$-caryophyllene and its oxide too (13). 


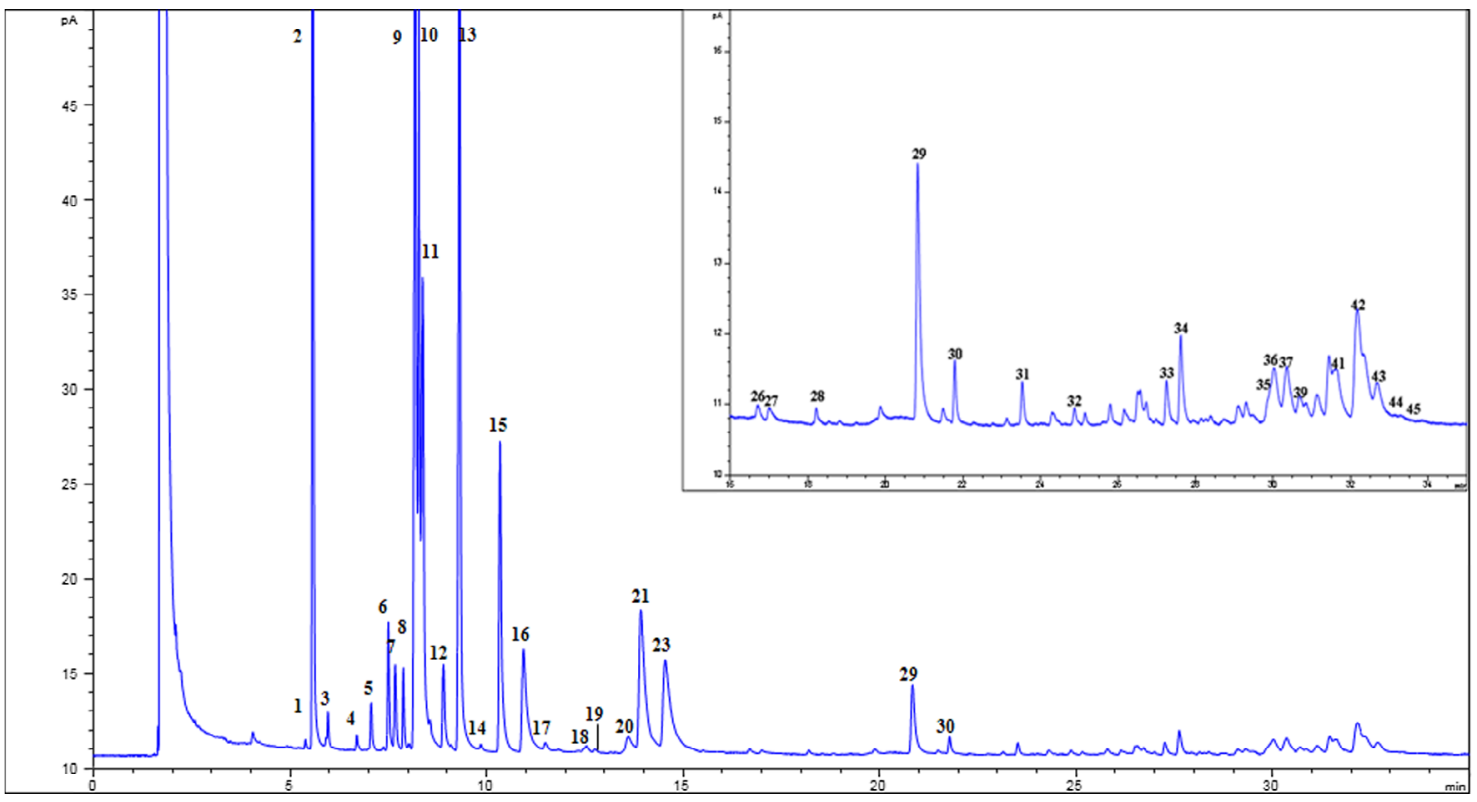

Figure 1. Representative chromatogram for the essential oil of P. laruotteanum.

Considering Psidium from different biomes, leaf oils from both P. pohlianum Berg and P. guyanensis Pers., from a semi-arid region (named Caatinga), were rich in 1,8-cineole (14). This compound was also found in high amounts in the oil of $P$. cattleianum Sabine, a species occurring in the Atlantic rainforest, although the major compound identified in this species was $\alpha$-thujene (15). A study on Psidium from the Amazon (16) revealed oils rich in $\beta$-caryophyllene and $\alpha$-selinene (P. striatulum Mart. ex DC.), $\beta$-bisabolol and limonene (P. guineense Sw.), $\alpha$-pinene and 1,8-cineole ( $P$. acutangulum DC., $P$. guajava L.).

P. guajava, guava tree is, by far, the most known and studied species of the genus. The essential oil from its leaves is rich in $\beta$-caryophyllene, although the compositions can vary greatly, which is not uncommon to a plant largely bred and cultivated (17).

Psidium is a genus largely distributed in Brazil, with sixty-six species, forty-four of them endemic and thirty-one found in the Cerrado biome. The species from the Cerrado are usually rich in sesquiterpenes, as shown by the data listed above. From our survey of aromatic plants from the Cerrado vegetation, it is quite unusual to find plants with predominance of monoterpenes. Still, albeit a great variability in oil profile has been described throughout the plants from different biomes, none of the Psidium oils investigated so far presented a similar composition to that of P. laruotteanum.

\section{Acknowledgements}

Y.F.M.F. thanks CNPq for a PIBIC scholarship.

\section{Disclosure statement}

No potential conflict of interest was reported by the authors.

\section{Funding}

This work was financially supported by the CNPq, FAPERJ, CAPES and Embrapa.

\section{ORCID}

Humberto R. Bizzo (D) http://orcid.org/0000-0001-5370-6478

\section{References}

1. R.C. Mendonça, J.M. Felfili, B.M.T. Walter, M.C. Silva Júnior, A.V. Rezende, T.S. Filgueiras, P.E. Nogueira and C.W. Fagg, Flora vascular do bioma Cerrado: checklist com 12356 espécies [Vascular flora of the biome Cerrado: checklist with 12356 species]. In: Cerrado: ecologia $e$ flora [Cerrado: ecology and flora]. Edits., S.M. Sarro, S.P. Almeida and J.F. Ribeiro, pp. 423-442, Embrapa Informação Tecnológica, Brasília-DF (2008).

2. R.F. Vieira, H.R. Bizzo and C. Deschamps, Genetic resources of aromatic plants from Brazil. Israel Journal of Plant Sciences, 58, 263-271 (2010).

3. Lista de Espécies da Flora do Brasil [List of the species from the flora of Brazil]. Jardim Botânico do Rio de Janeiro. http://floradobrasil.jbrj.gov.br/jabot/floradobrasil/ FB10871 (29 September 2017).

4. C.W. Fagg, E.N. Lughadha, W. Milliken, D.J. NicholasHind and M.G. Brandão, Useful Brazilian plants listed in the manuscripts and publications of the Scottish medic and naturalist George Gardner (1812-1849). Journal of Ethnopharmacology, 161, 18-29 (2015). 
5. L.K. Takao, M. Imatomi and S.C.J. Gualtieri, Antioxidant activity and phenolic content of leaf infusions of Myrtaceae species from Cerrado (Brazilian Savanna). Brazilian Journal of Biology, 75, 948-952 (2015).

6. S. Charneau, M.L. de Mesquita, I.M.D. Bastos, J.M. Santana, J.E.G. de Paula, P. Grellier and L.S. Espindola, In vitro investigation of Brazilian Cerrado plant extract activity against Plasmodium falciparum, Trypanosoma cruzi and T. brucei gambiense. Natural Product Research, 30, 1320-1326 (2016).

7. F.C.M. Medeiros, Caracterização química e atividade biológica de óleos essenciais de plantas do Cerrado contra fungos xilófagos [Chemical characterization and biological activity of essential oils from plants of the Cerrado against xylophagous fungi]. M.Sc. Dissertation, Universidade de Brasília, Brasília-DF (2014).

8. Wiley Registry of Mass Spectral Data, 6th edn., Wiley Interscience, New York, NY (1994).

9. H. Van Den Dool and P.D.J.A. Kratz, A generalization of the retention index system including linear temperature programmed gas-liquid partition chromatography. Journal of Chromatography A, 11, 463-471 (1963).

10. R.P. Adams, Identification of Essential Oil Components by Gas Chromatography/Mass Spectrometry, 4th ed.., Allured Publ. Corp, Carol Stream, IL (2007).

11. R.C. Albino, P.C. Oliveira, F. Prosdocimi, O.F. da Silva, H.R. Bizzo, P.E. Gama, C.M. Sakuragui, C. Furtado and
D.R. de Oliveira, Oxidation of monoterpenes in Protium heptaphyllum oleoresins. Phytochemistry, 136, 141-146 (2017).

12. F.C.M. Medeiros, C.H.S. Del Menezzi, H.R. Bizzo and R.F. Vieira, Scents from Brazilian Cerrado: Psidium myrsinites DC. (Myrtaceae) leaves and inflorescences essential oil. Journal of Essential Oil Research, 27, 289-292 (2015).

13. M.O. Freitas, S.M.D. Morais and E.R. Silveira, Volatile constituents of Psidium myrsinoides O. Berg. Journal of Essential Oil Research, 14, 364-365 (2002).

14. M. Neto, J.W.D. de Alencar, A.N. Cunha, E.R. Silveira and T.G. Batista, Volatile Constituents of Psidium pohlianum Berg, and Psidium guyanensis Pers. Journal of Essential Oil Research, 6, 299-300 (1994).

15. F.A. Marques, E.P. Wendler, B.H.L.N.S. Maia, J.V. CoffaniNunes, J. Campana, and P.G. Guerreiro, Volatile oil of Psidium cattleianum Sabine from the Brazilian Atlantic Forest. Journal of Essential Oil Research, 20, 519-520 (2008).

16. J.D.D. da Silva, A.I.R. Luz, M.H.L.D. da Silva, E.H.A. Andrade, M.D.G.B. Zoghbi and J.G.S. Maia, Essential oils of the leaves and stems of four Psidium spp. Flavour and Fragrance Journal, 18, 240-243 (2003).

17. M.E.A. Stefanello, A.C.R.F. Pascoal and M.J. Salvador, Essential oils from neotropical Myrtaceae: Chemical diversity and biological properties. Chemistry and Biodiversity, 8, 73-94 (2011). 